\author{
Abstracta Iranica \\ Abstracta Iranica Revue bibliographique pour le domaine irano-aryen \\ Volume 32-33 | 2013 \\ Comptes rendus des publications de 2009-2010
}

\title{
Abdukholiq Nabavī. Justorho va ibtikorot dar nasr
}

\section{Evelin Grassi}

\section{(2) OpenEdition}

\section{Journals}

Electronic version

URL: http://journals.openedition.org/abstractairanica/40997

DOI: 10.4000/abstractairanica.40997

ISSN: 1961-960X

\section{Publisher:}

CNRS (UMR 7528 Mondes iraniens et indiens), Éditions de l'IFRI

\section{Printed version}

Date of publication: 1 December 2013

ISSN: 0240-8910

\section{Electronic reference}

Evelin Grassi, «Abdukholiq Nabavī. Justorho va ibtikorot dar nasr », Abstracta Iranica [Online], Volume 32-33 | 2013, document 442, Online since 01 July 2016, connection on 03 October 2020. URL : http:// journals.openedition.org/abstractairanica/40997 ; DOI : https://doi.org/10.4000/abstractairanica. 40997

This text was automatically generated on 3 October 2020.

Tous droits réservés 


\title{
Abdukholiq Nabavī. Justorho va ibtikorot dar nasr
}

\author{
Evelin Grassi
}

\section{REFERENCES}

Abdukholiq Nabavī. Justorho va ibtikorot dar nasr. Dushanbe, Adib, 2009, 322 p.

[Discoveries and innovations in prose-writings]

1 The discoveries and innovations to which the Tajik scholar Abdukholiq Nabavī is referring are the new trends in the 20th century Tajik Jadidist, Soviet and post-Soviet prose, in particular the works of Abdurrauf Fitrat, Sadriddin Aynī, Rahim Jalil, Fazliddin Muhammadiev, Abdumalik Bahorī and Iskandar Doro among others.

2 The first (p. 7-70) of the five chapters deals with the works of the masters (Ustod) of Tajik prose. It focuses on two bilingual (Tajik-Uzbek or Uzbek-Tajik) intellectuals and men of letters: Abdurrauf Fitrat (1886-1938) and Sadriddin Aynī (1878-1954). Although Aynī is commonly regarded as the founder of modern Tajik literature in general and prose in particular, Nabavi emphasizes that the first 20th century realistic Turkestanian prose writings in Persian, relevant for the development of realism in Tajik literature, were by Fitrat. Indeed, Fitrat published Munozara [The debate] and Bayonoti sayyohi hind [The manifesto of an Indian traveller] in 1909 and 1912 respectively, whereas Ayni’s first novelette, Sarguzashti yak tojiki kambaghal yo ki Odina [The misadventures of a poor Tajik, or Odina], came out in 1924. Chapters two, three and four are devoted to Tajik Soviet prose with a paragraph on the Tajik historian Bobojon Ghafurov (1908-1977) and the representation of history in Tajik prose (p. 85-94). The final chapter addresses issues related to the country's independence after the collapse of the Soviet Union (1991) and this event's repercussions on Tajik prose. 


\section{AUTHORS}

\section{EVELIN GRASSI}

Université de Naples 